\title{
衝撃工学の最前線 The Front Line of Impact Engineering
}

材料や構造物の衝撃問題は古くて新しい問題である，材料の観点からは，その応力一ひずみ曲線がひずみ速度効果に より形状が変化することが知られている．構造物の観点からは，種々の応力波がその内部を伝ぱしていくことにより静 的解析とは著しく異なる応力分布が発現することが知られている。個々の現象について詳細が明らかになっても，それ らを総合的に構造設計の実務に過不足なく取り込んでいくことは容易ではない.

日本の数ある業界の中でも，特に鉄鋼業界や自動車業界はひずみ速度 $10^{3} \mathrm{~s}^{-1}$ オーダでの高速引張試験をかなり前から 取り入れて製品設計に反映してきた。ここでの成果は，その他の分野の材料や製品の設計にすばやく展開されるべきも のである，衝撃部門委員会では，吕のような動きをさらに加速させるため，衝撃工学フォーラムを毎年開催してきてい る.この講座では, 平成 20 年と 21 年に開催した第 7 回と第 8 回の衝撃工学フォーラムで講師を務めていただいた方々 に，あらためてその専門分野に打ける衝撃問題への取り組みについて解説を打願いした。

衝撃問題に現在取り組まれている方々はもとより, これから取り組もうとされている方々の抢役に立てば幸いである.

内 容

1. 高速引張試験機のラウンドロビンテスト結果と材料研究への展開

(JFE スチール) 高木 周作

2. 高速衝撃現象の数值解析法

3. スポット溶接破断予測モデルの開発と実車衝突設計への応用

(伊藤忠テクノソリューションズ) 片山 雅英

4. 自動車の衝突安全における衝撃と人体傷害

(新日本製鐵) 吉田 博司

5. 土木建築に打ける最近の衝撃問題について

(日本自動車研究所) 江島晋

(金沢大) 栘谷浩

(防衛大) 藤掛 一典

\section{1. 高速引張試験機のラウンドロビンテスト結果と材料研究への展開}

高 木 周 作*

\section{I : Round Robin Test Results of High Strain Rate Tensile Test Machines and an Advanced Application to Study of High Strain Rate Deformation Behavior of Materials}

by

\author{
Shusaku TAKAGI ${ }^{*}$
}

\begin{abstract}
Key words : High strain rate tensile test, Steel sheet, Hopkinson pressure bar, One bar method, Sensing block
\end{abstract} testing system, Hydraulic tensile equipment

1 緒言

新興国では自動車需要の高まりとともに, 自国の自動 車メーカーが台頭しつつあり, 自動車業界の競争は激化 している.さらに, $\mathrm{CO}_{2}$ 排出規制の強化，衝突安全規制の 強化等, 種々規制への対応も増加している。これらの多 種多様な制約の中で，目標を満足する車体をタイムリー かつ低コストで開発することが自動車メーカーでは重要 となっている.

自動車車体開発の重要課題の一つに衝突安全性の維 持・向上がある。衝突安全性は車体設計時に CAE 解析
により予測され，試作車の衝突試験により確認される。 目標性能を確実に達成するためには，車体設計時の衝突 特性の予測精度を向上させることが重要である。

車体の衝突特性の予測には, 素材の応力 (Stress)一ひ ずみ (Strain) 曲線（以降 S-S 曲線）データが必要とな る. 衝突時の部材の変形のひずみ速度は部位によって異 なり, $10^{-3} / \mathrm{s} \sim 10^{3} / \mathrm{s}$ に分布すると推定されている. ${ }^{1)}$ 自 動車車体の主な構成材料である鋼板は bcc 金属であり, 流動応力のひずみ速度依存性が大きいことが知られてい る.'図 1 に高張力鋼板の S-S 曲線のひずみ速度増加に伴

$\dagger \quad$ 原稿受理 平成 22 年 7 月 29 日 Received July 29, 2010 (C) 2011 The Society of Materials Science, Japan

* JFE スチール(株)スチール研究所 †260-0835 千葉市中央区川崎町, JFE Steel Co. Steel Res. Laboratory, Chuo-ku, Chiba, 260-0835 


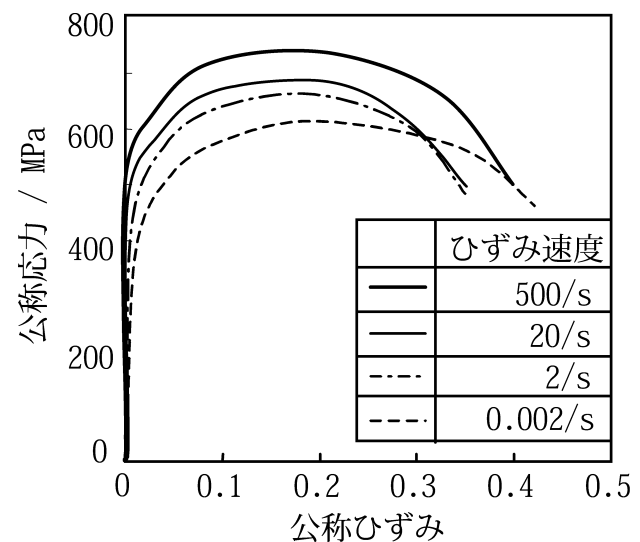

図 $1590 \mathrm{MPa}$ 級複合組織鋼の S-S 曲線のひずみ速度 依存性

う変化の一例を示す，ひずみ速度が 500/s では，0.002/s と比較して, 流動応力が $20 \%$ 前後上昇する。年のため, CAE により車体の衝突特性を精度良く予測するために は，使用する材料特性にひずみ速度依存性を精度良く反 映させることが必要となる。例えば IF 軟鋼と $590 \mathrm{MPa}$ 級 鋼について, ハット型部材を $11 \mathrm{~m} / \mathrm{s}$ で圧潰し, 吸収エネ ルギーについて FEM シミュレーション結果と比較した例

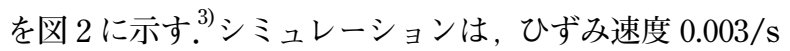
の S-S 曲線データのみを使用したケース (FEM (static)) と, $10^{3} / \mathrm{s}$ までの S-S 曲線のひずみ速度依存性を反映した ケース (FEM (dynamic)) について行った. FEM (dynamic)は, FEM (static)よりも実験值とよく一致している. この結果からも明らかなように, 衝突解析精度の向上に は, S-S 曲線のひずみ速度依存性を考慮することが重要 であり，解析に使用される S-S 曲線データ精度の向上は シミュレーション精度向上に必要不可欠である。

さて, S-S 曲線は通常引張試験により取得され，ひず 及速度 $10^{\circ} / \mathrm{s}$ 程度以下の低速での静的引張試験の方法は

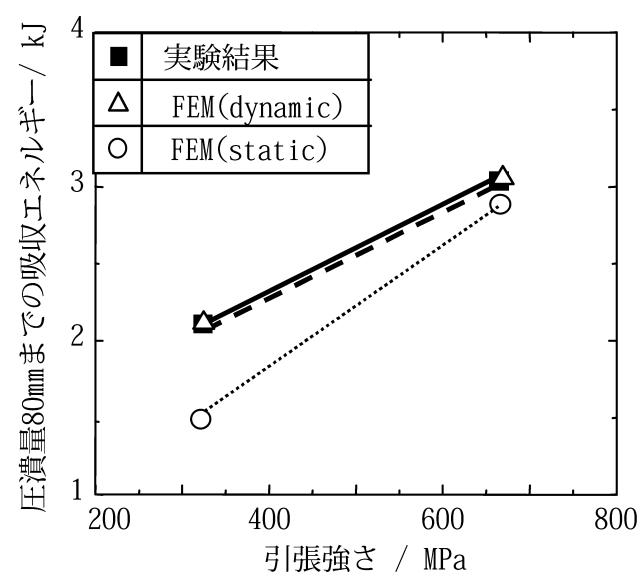

四 2 ハット型圧潰試験における実験とシミュレーショ ン結果の比較

FEM (dynamic) ：S-S 曲線のひずみ速度依存性を考 虑したシミュレーション結果

FEM (static) ：S-S 曲線のひずみ速度依存性を考 慮しないシミュレーション結果
$\mathrm{JIS}^{4)}$ や $\mathrm{ISO}^{5)}$ で規格化されている。しかし，ひずみ速度 $10 \%$ 以上の引張試験を従来の静的引張試験機を用いて 行うと, 図 3 に示すように, S-S 曲線データに応力振動 が重畳し, 正確な S-S 曲線データが取得できない. ${ }^{6}$ ここの 原因は, 高ひずみ速度变形時には応力がパルス状の応力 波として伝ぱし, ロードセル内で反射を繰り返すためで ある. この問題点を解決し, 高速変形時の S-S 曲線を精 度良く測定するために, 日本では種々の装置が開発, 使 用されている。しかし, それらの装置は, 応力, ひずみ の測定原理, 装置の構成等が異なっているため, 同一材 料で試験を行っても, 得られる S-S 曲線データに差が生 じる可能性がある.

本稿では, 同一材料を用いて 5 種類の高速引張試験装 置により S-S 曲線を測定, 比較するラウンドロビンテス 卜の結果 ${ }^{3), 7)}$ を紹介し, 各装置の特徴打よびデータの使 用上の注意点について述べる。ささらに, 測定された S-S 曲線データから, 材料の高速変形挙動について得られた 新たな知見 ${ }^{8}$ を紹介し, 材料の高速変形挙動解明への高 速引張試験データの利用の可能性について述べる.

\section{2 高速引張試験装置と測定原理}

本節では, ラウンドロビンテストに使用した装置の測 定原理と装置構成例を簡単に紹介し, 高速引張試験を実 施する際の注意点についても述べる. 各装置に関する詳 細な内容は，参考文献を参照いただきたい。

\section{$2 \cdot 1$ 高速引張試験装置と測定原理}

高速引張試験時の応力を正確に測定する手法には, ロー ドセルを長尺化する手法と, 反対に短尺化する手法があ る. 長尺化する手法は, ロードセル内で反射する応力波 を重畳のない状態で測定することを狙いとして打り，木 プキンソン棒法を原型とする。一方, 短尺化する手法は, ロードセル内で反射する応力波を極短時間で平均化する ことを狙いとして抢り，主として油圧サーボを利用した 試験機に採用されている.

$2 \cdot 1 \cdot 1 \quad$ ホプキンソン棒法を原型とした装置 ホプ キンソン棒法は, 高速圧縮試験方法として 1940 年代に 開発され ${ }^{9)}$ ひずみ速度 $10^{2} \sim 10^{3} / \mathrm{s}$ のオーダーでの試験 が可能である. 図 4 に圧縮型のホプキンソン棒法の模式 図を示す。試験片の両端に配置された長さ数メートルの 入力棒, 出力棒と呼ばれる丸棒 (まとめて, 応力棒と呼 ぶ）をロードセルとして使用する. 入力棒を打撃するこ

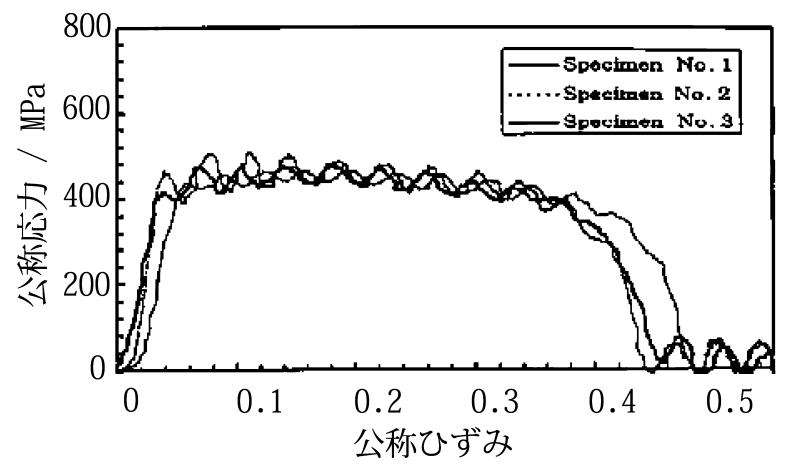

図 3 高速引張試験時に計測される応力振動 ${ }^{6)}$ 


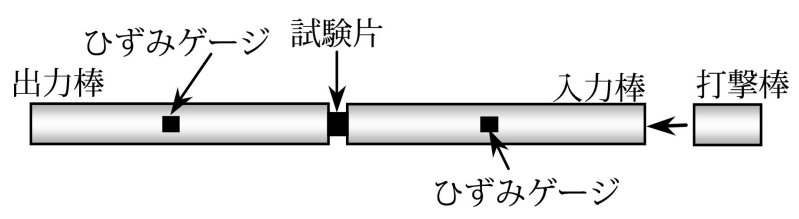

図 4 圧縮型ホプキンソン棒法の模式図

とにより圧縮の弾性波を入力し，他端に接合された試験 片を圧縮する。入力した応力波は一部が試験片内に透過 し，残りは入力棒内を反射する。各応力波は一般的な条 件では持続時間数百 $\mu \mathrm{s}$ のパルス状であり, 応力棒の長 さを数 $\mathrm{m}$ にすることで入力波と反射波打よび試験片を経 由して出力棒に伝わった透過波を互いの干渉なく独立に 計測できる、試験片の変形中の応力とひずみは，これら の応力波データから計算により求める。しかし, 図 4 の 装置では, 引張試験が実施できないため, 試験機の構成 を工夫した高速引張試験機が開発された．以下にホプキ ンソン棒法を原型とした高速引張試験機のうち，今回用 いた 3 種類の装置について述べる.

(1) 共軸型ホプキンソン棒法 ${ }^{10), 11)}$ (Coaxial Sprit

\section{Hopkinson Pressure Bar)}

装置構成を図 5 に示す。入力棒の先端に配置されたフ ランジを中空の打撃管により打撃し, 入力棒に応力波を 入力し, 試験片を引張変形させる. 試験片の応力とひず みはホプキンソン棒法と同一の方法で求める。試験片は つかみ部に空けられた穴にピンを通して專用の治具にセッ 卜された後, さらに強固に治具と接着され，応力棒に取 り付けられる。

(2) 非共軸型ホプキンソン棒法 ${ }^{12), 13)}$ (Non-Coaxial Sprit

\section{Hopkinson Pressure Bar)}

装置構成を図 6 に示す。この装置は，共軸型ホプキン ソン棒法よりも簡便に試験片を着脱できるように，応力 棒および試験片の中心軸をずらして配置している。試験 片は応力棒の先端にはめ込まれたピンを試験片つかみ部 に空けられた穴に通して応力棒に連結される，応力棒と 試験片の中心軸の位置がずれているために試験片および 応力棒に曲げモーメントが発生することが懸念されるが, FEM 解析により曲げモーメントは S-S 曲線に影響を与え ないレベルであることが確認されている. ${ }^{14)}$

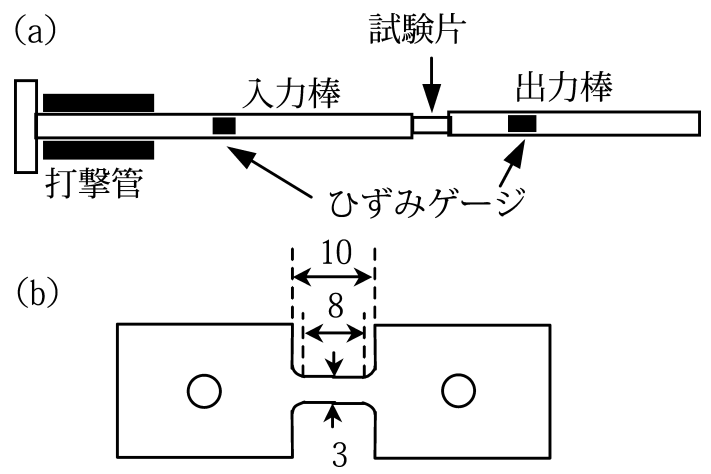

図 5 共軸型ホプキンソン棒法 (a) 試験機構成, (b) 試験片形状例

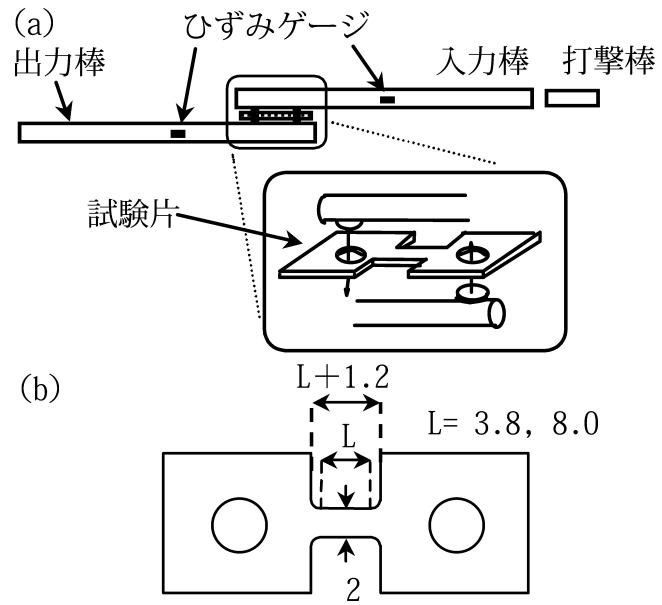

図 6 非共軸型ホプキンソン棒法 (a) 試験機構成，(b) 試験片形状例

(3) ワンバー法 (One Bar) ${ }^{15), 16)}$

ホプキンソン棒法は応力棒が長いほど，より低ひずみ 速度および高ひずみ域までのデータ採取が可能である。し かし, 応力棒が長くなると, 試験機長が長くなり，応力 棒の軸調整がより困難となる。そこで，入力棒の代わり に長さの短いインパクトブロックを介して応力波を試験片 に伝達するワンバー法が開発された。装置構成を図 7 に 示す. 本手法では，応力は出力棒に透過してきた透過波 より求め，ひずみ速度やひずみはインパクトブロックの 変位と応力棒の変位から算出される。試験片は，共軸型 ホプキンソン棒法と同様に，つかみ部に空けられた穴に ピンを通して専用の治具にセットされた後，さらに強固 に治具と接着され，出力棒とインパクトブロック間に取 り付けられる。

$2 \cdot 1 \cdot 2$ 油圧サーボを用いた試験機 油圧サーボを 利用すれば，試験片を高速で変形させることが可能であ るが，ホプキンソン棒法のようなロードセルの長尺化は困 難である。そこで，逆に，ロードセルを小型化し，ロード セル内で反射する応力波を極短時間で定常化し，応力を 計測する装置が開発されている。

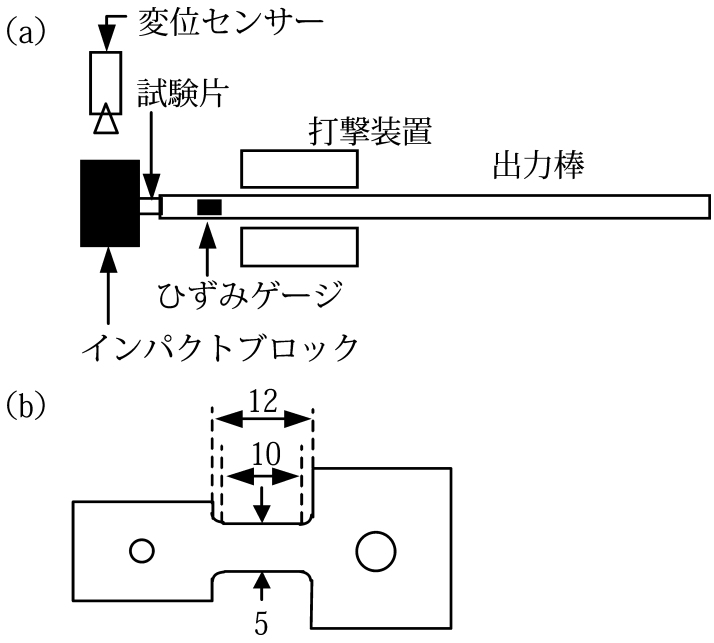

図 7 ワンバー法

（a）試験機構成，（b) 試験片形状例 
(1) 検カブロック式材料試験機 ${ }^{17) ~ ~ 19) ~}$

装置構成を図 8 に示す. ロードセルは直径数 $\mathrm{mm}$, 長さ 十数 $\mathrm{mm}$ と小型で，ロードセル内の応力波はごく短時間 で反射を繰り返し定常状態となる。さらに，このロードセ ルは大きなベースブロックの上に配置することで，ロード セルからベースブロックに透過した応力波をべースブ ロック内でほぼ消失させる。そのため，ロードセル内へ の反射波の再侵入はほとんどなく応力振動が抑制され， 安定した応力データが得られる。試験片はつかみ部にあ けられた穴にこのロードセルを通して固定され，試験片 の下部を加速されたロードブロックで打撃し，平行部に 引張変形を与える。ひずみおよびひずみ速度はロードブ ロックの変位より装置剛性を考慮して算出される.

(2) 油圧サーボ法

油圧サーボを利用した引張試験機は種々あるが，本報 告では試験片を極短時間で設定速度に到達させるための 加速機構を有する試験機を使用した。試験片はつかみ部 に空けられた穴にピンを通して試験機上下ロッド間にセッ トされる. 下ロッドが直径数 $\mathrm{mm}$ 長さ十数 $\mathrm{mm}$ の小型ロー ドセルとなっており，上ロッドは油圧サーボ試験機の駆 動系と間接的に接続され，試験機駆動系の加速（助走区 間）後試験片が変形する機構となっている. 変位は上ロッ ド移動量として測定する。

\section{$2 \cdot 2$ 高速引張試験における留意点}

高速引張試験は, 応力棒や試験片を適切にセッティン グして初めて精度のよいデータが得られる．以下に高速 引張試験時の留意点を簡単に述べる，各試験機における 測定精度向上の検討については，文献 6)，20), 21)を参 照されたい.

\section{(1) 試験機と試験片の配置}

高速引張試験では, 試験機（応力棒，打撃棒，インパ

(a)

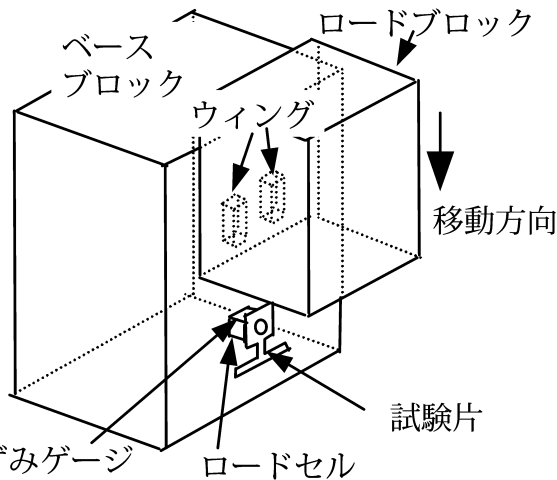

(b)

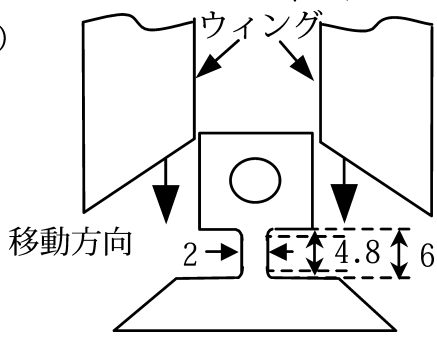

図 8 検力ブロック式材料試験機 (a) 試験機構成，(b) 試験片形状例
クトブロック，ロッド）および試験片の軸を平行に調整 することが重要であり，ずれが大きくなると S-S 曲線に 振動やノイズが発生することがある。

(2) 入力波形の制御

応力棒やインパクトブロックへの入力波形に振動やノ イズが生じると S-S データに影響を及ぼす。入力棒やイ ンパクトブロックを精度良く打撃し，きれいな形の入力 波を得ることが重要である。

\section{(3) 試験片の固定方法}

$2 \cdot 1$ 節で述べたとおり, 高速引張試験では試験片の両 端をピンで固定する手法をとる場合が多い．ピンのみで の固定は簡便であるが，ピン穴周囲の変形やピンと試験 片の間の遊びにより応力に乱れが生じる可能性がある。 そのため, 変形が平行部のみで生じるように, 可能な限 り試験片と試験機を強固に固定し, さらにつかみ部の変 形を抑制する工夫を加えることが好ましい，例えばワン

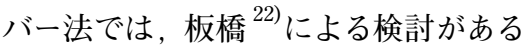

\section{（4）試験片平行部および肩 $\mathbf{R}$ 形状の選定}

高速引張試験では，ひずみは試験片平行部から直接検 出されるケースは少なく, 試験片が固定されている応力棒 やインパクトブロック，ロッド間隔から算出されるため， 平行部と肩 $\mathrm{R}$ 部の両方の変形量を検出している．よって, 理想的には肩 $\mathrm{R}$ 部分の変形を抑制し, 平行部のみを変形 させる必要がある。しかし，肩 Rの変形を抑制すると， 平行部の一部分の変形も抑制される場合があるため，試 験片平行部と肩 $\mathrm{R}$ の形状のバランスを最適化することは 重要であり，例えば，広瀬らの提案 ${ }^{23)}$ がある。

\section{3 ラウンドロビンテスト結果}

各試験機について，第 2 章で述べた留意点について検 討した後に，同一材料を用いて S-S 曲線データを取得し， 比較した

\section{$3 \cdot 1$ 供試材}

供試材は，IF 軟鋼および $590 \mathrm{MPa}$ 級フェライトーマル テンサイト複合組織鋼を用いた。図 9 に各装置で使用し た試験片の平行部のサイズおよび肩 $\mathrm{R}$ を示す，板厚はい ずれも $1.2 \mathrm{~mm}$ である.

\section{$3 \cdot 2$ 引張試験結果 ${ }^{3), 7)}$}

$3 \cdot 2 \cdot 1$ ひずみ速度 $500 / \mathrm{s}$ 以上での応カーひずみ曲 線 困 10 に IF 軟鋼の 500/s 以上ひずみ速度での S-S 曲

\begin{tabular}{|c|c|c|c|}
\hline \multirow[b]{2}{*}{ 装置 } & \multicolumn{3}{|c|}{ 試験片 } \\
\hline & $\begin{array}{c}\text { 平行部幅 } \\
/ \mathrm{mm}\end{array}$ & $\begin{array}{c}\text { 平行部長さ } \\
\text { /mm }\end{array}$ & 肩 $\mathrm{R}$ \\
\hline 共軸型杖 キンツ棒法(京大) & 3.0 & 8.0 & 1.0 \\
\hline 非共軸型ホプキンツ棒法(JFE) & 2.0 & $3.8,8.0$ & 0.6 \\
\hline ワンバー法（JFE） & 5.0 & 10.0 & 1.0 \\
\hline $\begin{array}{r}\text { 検力ブロック式材料試験機 } \\
\text { (大阪府立大) }\end{array}$ & 2.0 & 4.8 & 0.6 \\
\hline 油圧サーボ法(JFE) & 2.0 & 3.8 & 0.6 \\
\hline 既存の試験機(JFE) & 2.0 & 3.8 & 0.6 \\
\hline
\end{tabular}

図 9 試験片形状 
線，公称ひずみ速度一公称ひずみ曲線および $10 \%$ ひずみ での公称ひずみ速度を示す. (a)〜 (d)が共軸型ホプキンソ ン棒，非共軸型ホプキンソン棒，ワンバー，検力ブロッ クにより得られた結果であり，(e)はそれらを重ねて示し た。ひずみ速度はひずみ $3 \sim 5 \%$ まで上昇し，それ以降 はほぼ一定であった。

S-S 曲線は，ひずみ $5 \%$ 以上では試験機によらずほぼ同 じであったが，ひずみ $5 \%$ 未満では試験機毎に異なって いた。ひずみ $5 \%$ 以上の領域ではひずみ速度は $500 / \mathrm{s}$ 1400/s の範囲で試験機により異なった条件となってい る. $3 \cdot 3$ 節で詳細を述べるように，ひずみ速度は流動応 力の増加量に対して対数で影響するため， 500/s 1400/s の範囲ではひずみ速度の変化による流動応力の変 化は小さい.よって, ひずみ $5 \%$ 以上では試験機によら ずほほ同じ S-S 曲線が得られると判断できる。一方，ひ
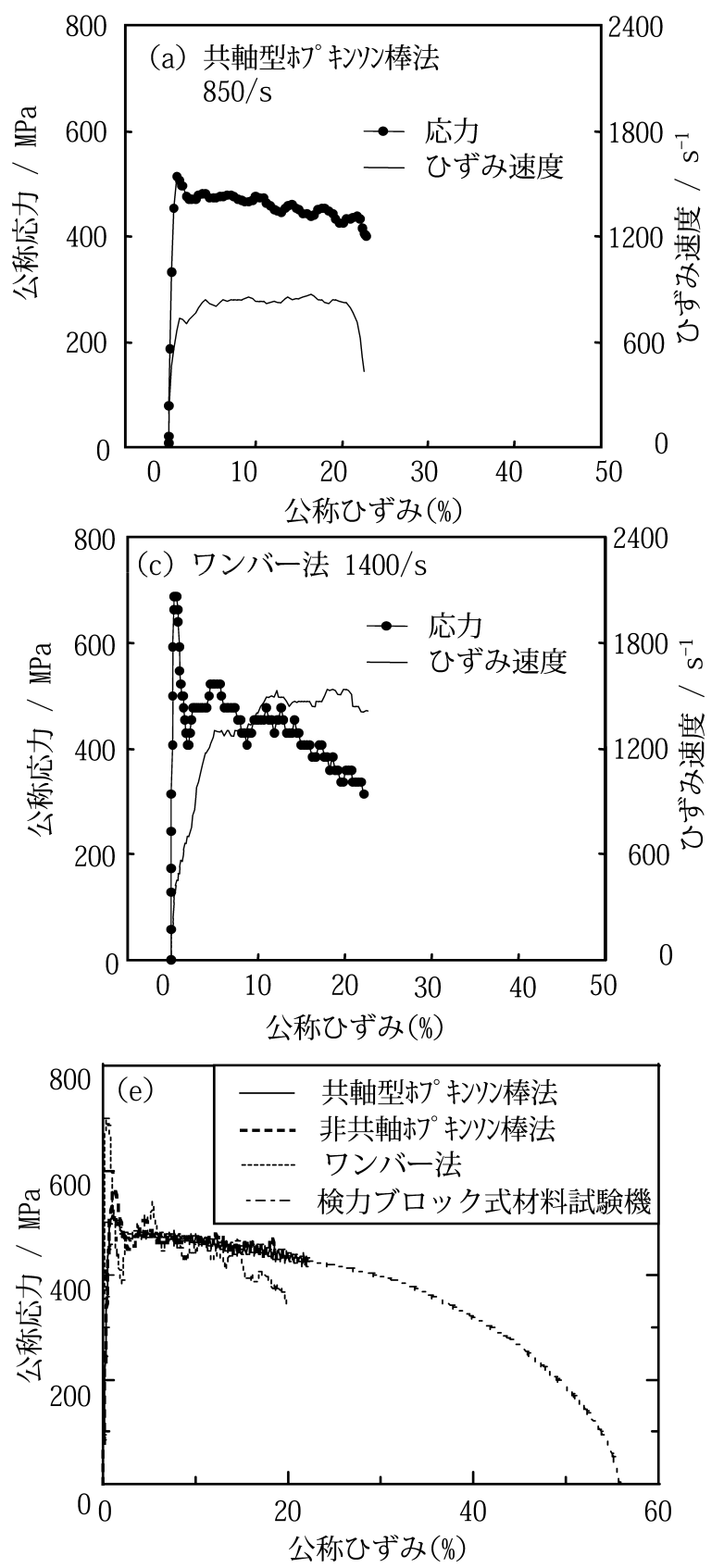

ずみ $5 \%$ 未満では，今回の結果では低ひずみ域での応力 ピークはワンバー法で最も高く，検力ブロック法では発 生せず，ホプキンソン棒法ではその中間となっていた。 この差が生じる原因は不明であるが，ひずみ速度の変化， 試験片の固定方法の差 ${ }^{22)}$ や入射波の乱れ等が考えられる. このピークは, $\mathbf{2} \cdot \mathbf{2}$ 節でも述べたように試験機のセッ ティング状態に大きく影響されるため, 試験前に標準サ ンプル等を用いて状態を確認・把握しておくことが好ま しい.

変形初期ピークは材料の降伏現象に対応する応力ピー クと試験機や入射応力波に起因して発生するノイズの両 者が含まれていると考えられる。どの初期ピークが正し いかは現在でも意見が分かれているが，低ひずみ速度変 形時には上降伏点が現れず連続降伏する IF 鋼やフェラ イトーマルテンサイト複合組織鋼, fcc 金属においても高
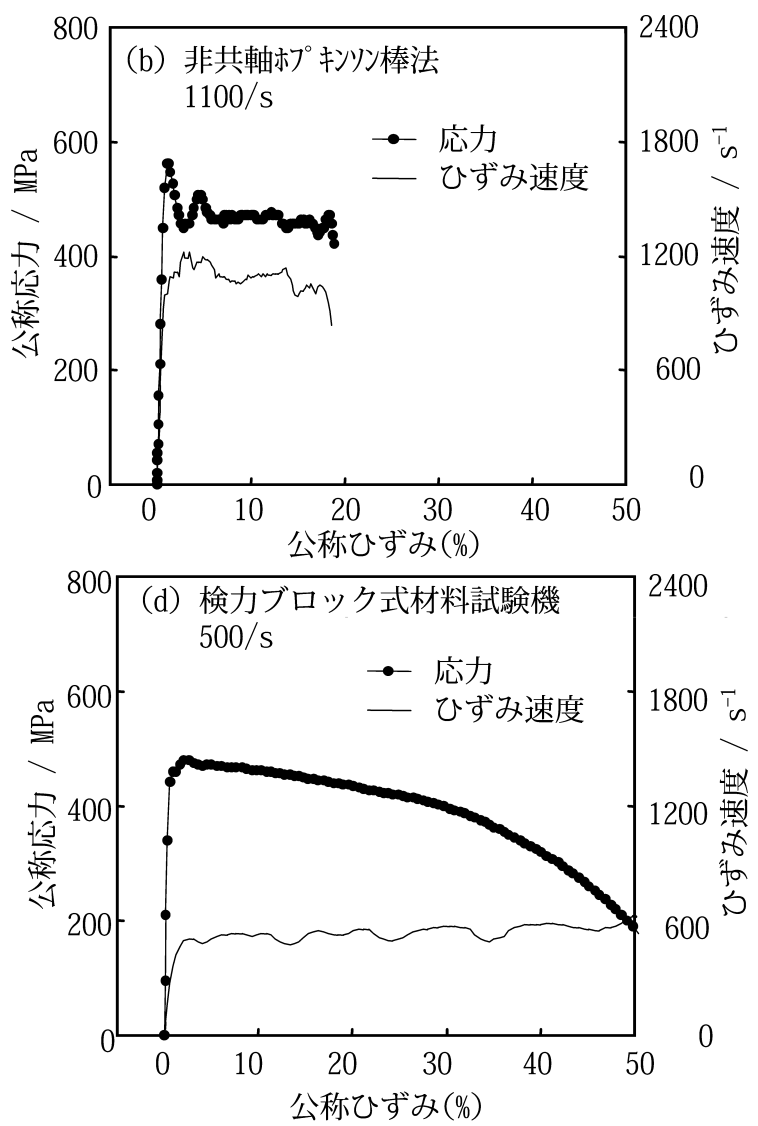

図 10 ひずみ速度 $500 / \mathrm{s}$ 以上での IF 軟鋼の応力ーひずみ曲 線とひずみ速度一ひずみ曲線
(a) 共軸型ホプキンソン棒法
(b) 非共軸型ホプキンソン棒法
(c) ワンバー法
(d) 検力ブロック式材料試験機
(e) (a)〜 (d)の S-S 曲線を全て記載 
ひずみ速度変形では降伏による応力低下現象が起こると される結果が多いように思われる，この現象は，低ひず み速度変形時には可動転位の移動や増殖により連続降伏 するが, 高ひずみ速度変形では変形速度が速いために可 動転位の移動や増殖だけでは変形が打いつかないため応 力が上昇し，転位の増殖速度が急激に増加しはじめると 応力低下が起こると考えることができる，今後も測定精 度や測定手法のさらなる高度化や治金学的な検討が継続 して行われ，真実が明確になることを期待する.

\section{$3 \cdot 2 \cdot 2$ ひずみ速度 $500 / \mathrm{s}$ 末満での応カーひずみ曲} 線 図 11 に検力ブロック式材料試験機，改良型油圧サー ボ試験機により得られた，ひずみ速度 $2 / \mathrm{s} \sim 200 / \mathrm{s}$ まで の S-S 曲線を示す． (a) には，既存のインストロン型引張 試験機で取得された $0.002 / \mathrm{s}$ での S-S 曲線もあわせて示 している．両試験機で得られた S-S 曲線はいずれのひず み速度においても，ひずみ $5 \%$ 以上ではほぼ一致してい る。ただし，検力ブロック法で得られた S-S 曲線は油圧 サーボ法で得られた S-S 曲線よりも応力振動が小さく, 応力測定精度が高い。また， $5 \%$ 未満の低ひずみ域での S$\mathrm{S}$ 曲線は, 特に変形初期ピークが両試験機で異なってお り，この結果では，検力ブロック法のピークよりも改良 型油圧サーボ法のピークのほうが大きかった。

$3 \cdot 3$ ラウンドロビンテストのまとめ 四 12 に, IF 軟鋼打よび $590 \mathrm{MPa}$ 級鋼について, 各種試験機で得られ たひずみ $10 \%$ での公称応力とひずみ速度の関係をプロッ トした結果を示す.いずれの試験機で得られた流動応力も ほぼ一つの曲線上にある。 Yada ら ${ }^{24)}$ は純鉄において，ひ ずみ速度がある基準のひずみ速度 $\varepsilon_{0}$ から $\varepsilon$ に増加した時 の流動応力の増分 $\Delta \sigma$ は式 (1)で表されると提案している.

$$
\Delta \sigma=K\left(\frac{\dot{\varepsilon}}{\dot{\varepsilon_{0}}}\right)^{1 / m^{*}}
$$

ここで, $K, m^{*}$ は定数である.

式 (1)を IF 軟鋼打よび $590 \mathrm{MPa}$ 級鋼に適用できると仮

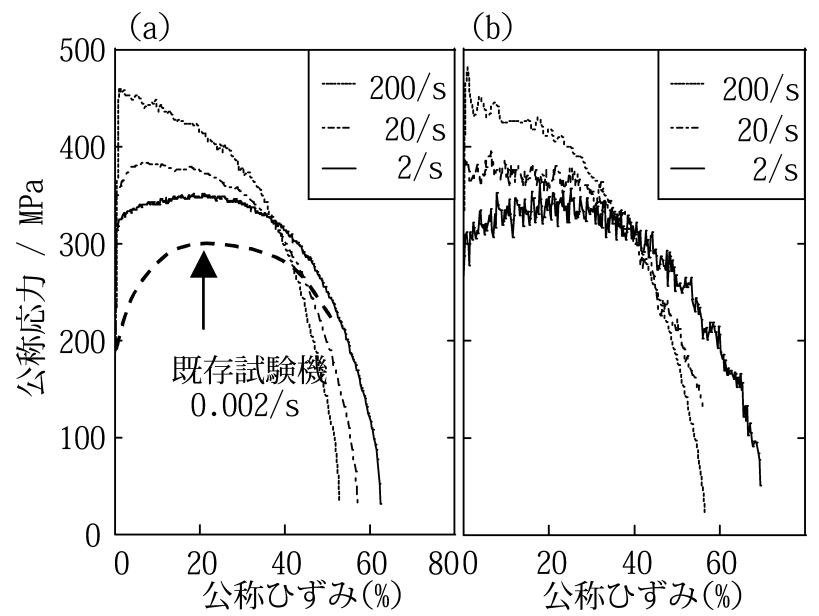

図 11 ひずみ速度 500/s 未満での IF 軟鋼の S-S 曲線

(a) 検力ブロック式材料試験機

(b) 油厓サーボ
定すると，図 12 のデータから両鋼種の公称ひずみ $10 \%$ で の $\mathrm{K}$ 抽び $m^{*}$ が求まる。求めた $K$ と $m^{*}$ を用いて，ひ ずみ速度 500/s と $1400 / \mathrm{s}$ での流動応力を推定した結果, 両者の差は IF 軟鋼で約 $10 \mathrm{MPa} ， 590 \mathrm{MPa}$ 級鋼で約 $15 \mathrm{MPa}$ となった。これらはひずみ速度 $10^{3} / \mathrm{s}$ 近傍での流 動応力レベルと比較すると， $5 \%$ 以下の差である。この結 果から, $3 \cdot 2 \cdot 1$ 項で示した 4 種の装置で得られたひず 久速度 $500 / \mathrm{s}$ 以上の領域での S-S 曲線はひずみ $5 \%$ 以上 ではほぼ同じと判断し，いずれの装置を用いても同等の S-S 曲線データが得られると結論できる。一方，ひずみ $5 \%$ 未満の低ひずみ域での S-S 曲線は装置によって異なる 場合が多いと考えられ，装置の特徴をよく理解してデー タを使用する必要がある。

\section{4 材料研究への高速引張試験結果の利用例}

材料の変形過程や変形挙動を理解することは，新たな 材料開発を行う際に大変重要である。材料の高速変形挙 動に関する研究は古くから行われており ${ }^{25)}$ 最近では種々 の高張力鋼板や超微細粒鋼の流動応力のひずみ速度依存 性についての研究 ${ }^{26)}$, 27) が行われている。しかし，静的 変形について行われてきたような S-S 曲線の詳細な解析 が行われた例は少ない，その原因のひとつとして，S-S 曲 線データの信頼性が不明確で，詳細な解析が行えなかっ
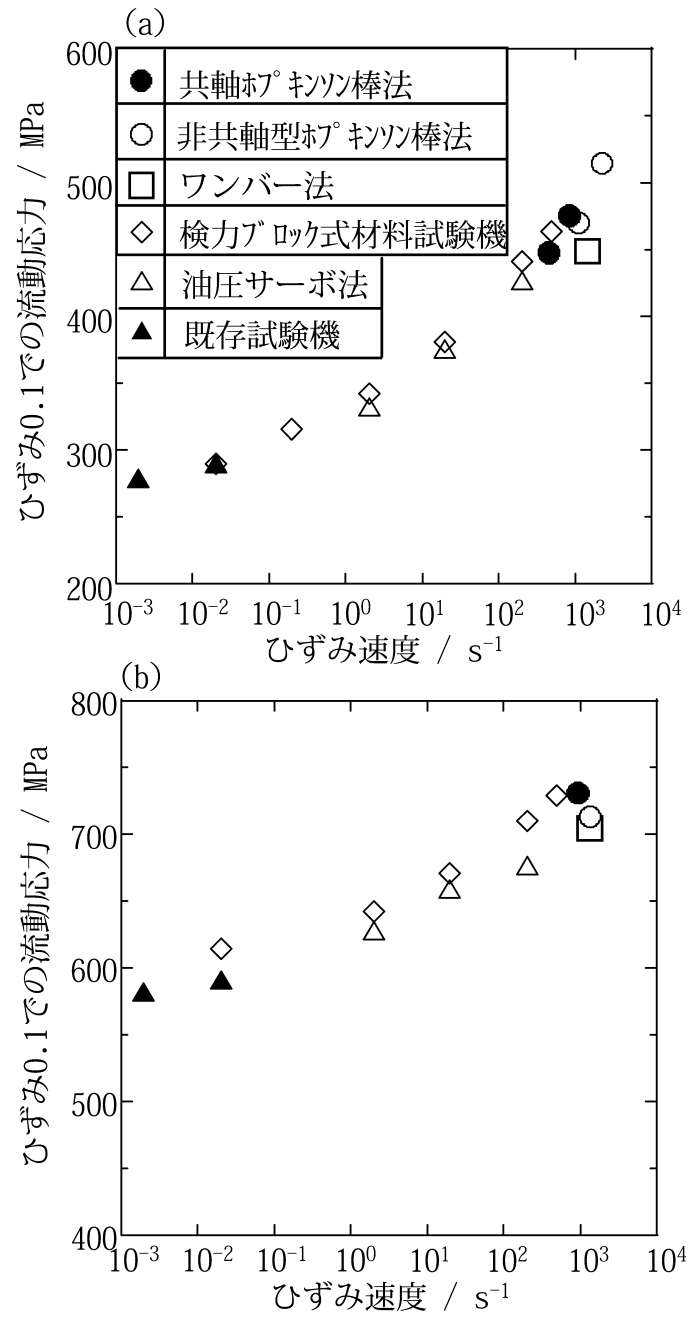

図 12 流動応力のひずみ速度依存性 (a) IF 軟鋼，（b) $590 \mathrm{MPa}$ 級鋼 
たことが考えられる．本ラウンドロビンテストの結果で は，ひずみ $5 \%$ 以上ではいずれの試験機でも同様の S-S 曲 線が得られたことから，試験機を適性に設定できれば S-S 曲線データの信頼性は高く，精緻な解析および議論が可 能と考えられる，以下に，IF 軟鋼と $590 \mathrm{MPa}$ 級鋼につい て，加工硬化率に及ぼすひずみ速度の影響について解析 を行った例 ${ }^{8)}$ を示す.

本検討により得られた S-S 曲線から加工硬化率の指標 である $\Delta \sigma / \Delta \varepsilon$ を求めた結果を図 13 に示す。 $\Delta \sigma / \Delta \varepsilon$ は, 一般的にはひずみの増加とともに単調に減少するが， IF

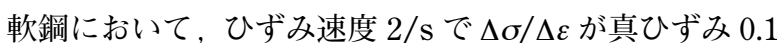
程度で極小となった後に上昇することが明らかとなった。 $590 \mathrm{MPa}$ 級鋼ではこのような現象は見られなかった。こ の変化の原因は調査中であるが，このような精緻な解析 が可能となることで，材料の高速変形挙動への理解が深 まり，新たな現象の発見や新たな材料開発が可能になる と期待される。

\section{5 結言}

5 種類の高速引張試験機を用いてラウンドロビンテス トを行った結果,
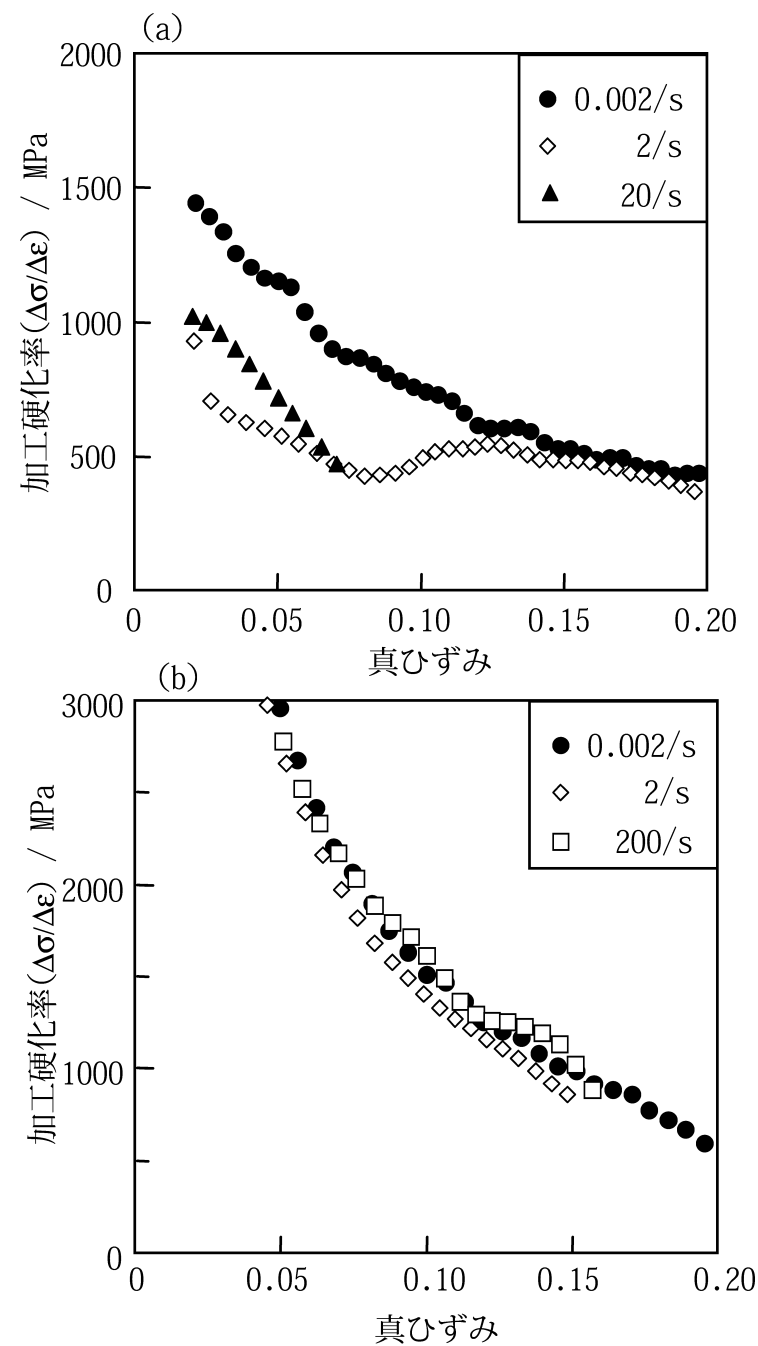

図 13 加工硬化率 $\Delta \sigma / \Delta \varepsilon$ の変化におよぼすひずみ速 度の影響

(a) IF 軟鋼，(b) $590 \mathrm{MPa}$ 級鋼
（1）いずれの装置を用いても，ひずみ $5 \%$ 以上ではほ ぼ同じ S-S 曲線が得られる。

(2) ひずみ $5 \%$ 未満では，装置毎に S-S 曲線が異なる 可能性が高く，その特徵を理解してデータを使用するこ とが重要である。

ことが明らかとなった。これらの結果から，ひずみ $5 \%$ 以 上の領域では，いずれの試験機でも得られる S-S 曲線デー 夕の信頼性は高く, S-S 曲線の詳細な解析やその結果に 基づいた考察，議論が可能と判断できる．また，異なる 試験機で採取されたデータでも，データの比較や相互利 用が可能と考えられる。ただし，得られる S-S 曲線は装 置や試験片のセッティング状態によって恋化するため， 試験前に装置の状態を確認することが好ましい。

高速引張試験に関するノウハウや試験装置に対する 種々の理解は世界の中で日本がもっとも進んでいるため， 高速引張試験方法の ISO 化を日本が議長国として推進し ている。規格はホプキンソン棒法，ワンバー法を対象と した弾性棒方式と油圧サーボ方式の 2 種類に分けて策定 されており，弾性棒方式については，2010年 2 月に規格 が発行された. ${ }^{28)}$ 油圧サーボ方式も続いて発行される予定 である。この規格化を契機に，精度の高い高速引張試験 データが蓄積されることが期待される.

高ひずみ速度下での S-S 曲線は今後も種々の分野で必 要とされるデータである，拙文が今後のデータ採取，解析 および金属学的な種々の検討を行う際の参考となり，多 くの研究者, 開発者の研究推進およびデータの相互利用 促進の一助となれば幸いである.

本報告は，JFE スチール(株)時田氏，佐藤氏，JFE テク ノリサーチ(株)橋口博士 清水氏，スペース・ダイナミック 不研究所 小川博士, 大阪府立大学教授 三村博士, 愛知 工科大学教授 谷村博士のご協力により得られたデータお よび議論を基にしたものであり，ここに記して謝意を表 する.

\section{参 考 文 献}

1) "The final report of research group on high-speed deformation of steels for automotive use”, p.5 (2001) The Iron and Steel Institute of Japan.

2 ) J. D. Campbell and W. G. Ferguson, "The temperature and strain-rate dependence of the shear strength of mild steel" Philosophical Magazine, Vol.21, Issue. 169, pp.63-82 (1970).

3 ) S. Takagi, Y. Tokita, K. Sato, T. Shimizu, K. Hashiguchi, K. Ogawa, K. Mimura and S. Tanimura, "Stress-strain curves of high strength steel sheets at strain rates from $10^{-3}$ to $10^{3} / \mathrm{s}$ obtained with various types of tensile testing machines”, SAE Transactions Journal of Materials and Manufacturing, Vol.114, No.5, pp.166-174 (2005).

4 ) "Method of tensile test for metallic materials", JIS Z 2241 ; 1998.

5 ) "Metallic materials -- Tensile testing - Part 1 : Method of test at room temperature”, ISO-6892-1 ; 2009.

6 ) Kinzokuzairyou no Kousokuhenkeitokuseihyoukahou no 
Kenkyuu Kaihatsu Jigyou Gyoumu Seika, New material center, (1999).

$7)$ S. Takagi, Y. Tokita, K. Sato, T. Shimizu, K. Hashiguchi, K. Ogawa, K. Mimura and S.Tanimura, "Stress-strain curves of steel sheets obtained by various methods of the high strain rate tensile test”, Society of Automotive Engineers of Japan Annual Congress Proceedings (2005 Spring) No.18-05, pp.9-12, (2005).

8 ) S. Takagi, T. Shimizu and K. Hashiguchi, "Work hardening behavior of steel sheets under high strain rate”, Proceedings of 2nd International Symposium on Steel Science 2009 (ISSS-2009) 【Strength, Plasticity and Fracture in Steels -Fundamentals and Novel Approaches for New demands-】 pp.166-174 (2009).

$9)$ H. Kolsky, "An investigation of the mechanical properties of materials at very high rates of loading", Proceedings of the Physical Society. Section B, Vol.62, No.11, pp.676-700, (1949).

10) K. Ogawa, "Temperature and strain rate effects on the tensile strength of 6061 aluminum alloy”, Impact engineering and applications, Proceedings of the Fourth International Symposium on Impact Engineering, pp.99-104 (2001).

11) T. Yokoyama, "Impact tension and compression testing of ductile cast iron with split hopkinson bar", Journal of the Society of Material Science, Japan, Vol.45, No.7, pp.785-791 (1996).

12) N. Kuriu and S. Tanimura, Proceedings of the 2nd Materials and Processing Conference (M \& P '94, JSME), Vol.940, pp.144-145 (1994).

13) K. Miura, S. Takagi, O. Furukimi, T. Obara and S. Tanimura, "Dynamic deformation behavior of steel sheet for automobile”, Society of Automotive Engineers Technical Paper, 960019, (1996).

14) T. Umeda, K. Mimura and S. Tanimura, "Evaluation of a few dynamic material tests by using numerical simulation”, Proceedings of the 2nd Materials and Processing Conference, No.02-05, pp.693-694 (2002).

15) K. Kawata, S. Hashimoto, K. Kurokawa and N. Kanayama, "A new testing method for the characterization of materials in high velocity tension” Mechanical properties at high strain rates of strain 1979, Institute of Physical. Conference, 47, Institute of Physics, Bristol and London, pp.71-80 (1979).

16) M. Itabashi and K. Kawata, "Carbon content effect on high-strain-rate tensile properties for carbon steels", International Journal of Impact Engineering, Vol.24, No.2, pp.117-131 (2000).

17) S. Tanimura, K. Mimura and T. Umeda, "New testing techniques to obtain tensile stress-strain curves for a wide range of strain rates", Journal de Physique IV France Vol.110, pp.385-390 (2003).

18) S. Tanimura and M. Aiba, "A trial to detect the generated impulsive force directly with high sensitivity”, Transactions of the Japan Society of Mechanical Engineers, A, Vol.49, No.448, pp.1565-1571 (1983).

19) S.Tanimura, K. Mimura and S. Takada, Proceedings of the 2nd Materials and Processing Conference, No.98-5B, pp.304305 (1998).

20) Kinzokuzairyou no Kousokuhenkeitokuseihyoukahou no Kenkyuu Kaihatsu Jigyou Gyoumu Seika, New material center, (2000).

21) Kinzokuzairyou no Kousokuhenkeitokuseihyoukahou no Kenkyuu Kaihatsu Jigyou Gyoumu Seika, New material center, (2001).

22) M. Itabashi, "High velocity tensile test method for thin plate with one bar method -For steel and aluminum alloys-”, Journal of the Japanese Society for Experimental Mechanics, Vol.2, No.2, pp.109-116 (2002).

23) S. Hirose, H. Yoshida, S. Yonemura, A. Uenishi, S. Hiwatashi and N. Suzuki, "Measurement technology of stress-strain curve in the range of high strain-rate -Advanced technologies related to crash simulation for optimum combination of structure and material, Part II-", Society of Automotive Engineers of Japan Annual Congress Proceedings (2009 Spring), No.15-06, pp.9-12 (2009).

24) H. Yada and H. Mimura, "The strain-rate and temperature dependence of effective flow stress in pure iron and some iron alloys", Journal of the Physical Society of Japan, Vol.24, No.6, pp.1269-1278 (1968).

25) S. Sakui, T. Nakamura and M. Ohmori, "The effects of grain size and deformation rate on the tensile properties of mild steel at low temperature : Studies of tensile properties of steels under high-speed impulsive loading IV”, Tetsu to Hagané, Vol.49, No.7, pp.996-1003 (1963).

26) S. Takagi, K. Miura, O. Furukimi, T. Obara, T. Kato and S. Tanimura, "Effect of strain rates on Strength of sheet steels", Tetsu to Hagané, Vol.83, No.11, pp.748-753 (1997).

27) N. Tsuchida, Y. Tomota and K. Nagai, "Tensile deformation behavior at high strain rate for ultrafine-grained ferrite-cementite steels" Tetsu to Hagané, Vol.90, No.12, pp.1043 1049 (2004).

28) "Metallic materials -Tensile testing at high strain rates-Part 1 : Elastic-bar-type systems”, ISO-26203-1; 2010. 